\title{
Mineralization of organic nitrogen from farm manure applications
}

Bhogal, A.; Williams, J. R.; Nicholson, F. A.; Chadwick, D. R.; Chambers, K. H.; Chambers, B. J.

\section{Soil Use and Management}

DOI:

10.1111/sum. 12263

Published: 01/06/2016

Peer reviewed version

Cyswllt i'r cyhoeddiad / Link to publication

Dyfyniad o'r fersiwn a gyhoeddwyd / Citation for published version (APA):

Bhogal, A., Williams, J. R., Nicholson, F. A., Chadwick, D. R., Chambers, K. H., \& Chambers, B. J. (2016). Mineralization of organic nitrogen from farm manure applications. Soil Use and Management, 32(S1), 32-43. https://doi.org/10.1111/sum.12263

\footnotetext{
Hawliau Cyffredinol / General rights

Copyright and moral rights for the publications made accessible in the public portal are retained by the authors and/or other copyright owners and it is a condition of accessing publications that users recognise and abide by the legal requirements associated with these rights.

- Users may download and print one copy of any publication from the public portal for the purpose of private study or research.

- You may not further distribute the material or use it for any profit-making activity or commercial gain

- You may freely distribute the URL identifying the publication in the public portal ?
}

Take down policy

If you believe that this document breaches copyright please contact us providing details, and we will remove access to the work immediately and investigate your claim. 


\section{Mineralisation of organic nitrogen from farm manure applications}

2 A. BHOGAL ${ }^{1 *}$, J.R. WILLIAMS ${ }^{2}$, F.A. NICHOLSON ${ }^{1}$, D.R. CHADWICK ${ }^{3}$, K. H.

3 CHAMBERS $^{4} \&$ B. J. CHAMBERS

$4{ }^{1}$ ADAS Gleadthorpe, Meden Vale, Mansfield, Notts. NG20 9PD, ${ }^{2}$ ADAS Boxworth,

5 Cambridge, CB23 4NN, ${ }^{3}$ Bangor University, ${ }^{3}$ School of Environment, Natural Resources

6 and Geography, Dieniol Road, Bangor, LL57 2UW, ${ }^{4}$ School of Agriculture, Food and

$7 \quad$ Rural Development, Newcastle University, Newcastle upon Tyne NE1 7RU

$8 \quad *$ Corresponding author: A. Bhogal; anne.bhogal@ adas.co.uk

$9 \quad$ Running Title: Manure organic N mineralisation

10 Abstract

11 This study aimed to quantify the amount of nitrogen $(\mathrm{N})$ mineralised from the organic fraction of farm manures under field conditions. Nine different farm manures were stripped of their ammonium-N content prior to soil incorporation and establishment of ryegrass at two sites in England. Grass $\mathrm{N}$ uptake and nitrate-N leaching were measured for five consecutive seasons and compared with an untreated control, with the sum of $\mathrm{N}$ uptake + leaching (net of the control) used as an estimate of the amount of organic $\mathrm{N}$ mineralised from the applied manures. The amount mineralised was related to thermal time (cumulative day degrees above $5^{\circ} \mathrm{C}-\mathrm{CDD}$ ), with two distinct phases - an initial phase up to $2300 \mathrm{CDD}$ (c.18 months under UK climatic conditions) where mineralisation proceeded at rates ranging between 0.005-0.027\% mineralised/CDD, and a slower phase at $>2300 \mathrm{CDD}$, where rates were negligible at $<0.001 \%$ mineralised/CDD. There was no difference between soil types, both being light-textured ( $<20 \%$ clay), but there were differences between manure types depending on the manure $\mathrm{C}$ : organic $\mathrm{N}$ ratios. For pig slurry and layer manure (C:organic $\mathrm{N}$

$24=9-12: 1)$ up to $70 \%$ of the organic $\mathrm{N}$ was mineralised, compared to $10-30 \%$ mineralisation 
from the cattle slurry and straw based FYMs (C:organic $N=10-21: 1)$.The relationships derived provide a useful tool for predicting both the amount and timing of manure $\mathrm{N}$ release, with important implications for both crop $\mathrm{N}$ uptake and leaching risk.

Keywords: Mineralisation, nitrogen, manure, organic matter, nitrate leaching, thermal time

\section{Introduction}

In the UK, around 93 million tonnes (fresh weight) of farm manures (cattle, pig and poultry manures) are recycled to agricultural land supplying c.405,000 tonnes of total nitrogen $(\mathrm{N})$ annually (Nicholson et al., 2008). Typically, $75-90 \%$ of the total $\mathrm{N}$ content of straw-based farmyard manures (FYM) is present as organic N, 50-60\% for poultry manures and $30-50 \%$ for slurries (Anon., 2010), with the remainder as readily available $\mathrm{N}$ (principally ammonium and uric acid-N for poultry manures). Research efforts have largely focused on manure readily available $\mathrm{N}$ forms, because in the short-term these have the greatest influence on crop N supply, ammonia volatilisation and nitrate leaching losses (Jarvis \& Pain, 1990; Unwin et al., 1991; Chambers et al., 1997). However, in the longer-term manure organic $\mathrm{N}$ release will have an increasingly important effect on soil $\mathrm{N}$ supply, particularly in situations where repeated manure applications are made to land (Schröder et al., 2007). If manure organic $\mathrm{N}$ release occurs during periods of crop growth (spring-summer) fertiliser $\mathrm{N}$ requirements will be reduced, but if release occurs during the autumn-winter period, nitrate leaching and denitrification losses are likely to be increased.

A key requirement of the Nitrate Vulnerable Zones Action Programme (NVZ AP) in England (SI, 2008) is for farmers to formally take into account the crop available N supply from livestock manure applications. This requires the use of manure $\mathrm{N}$ use efficiency (NUE) 
coefficients (or fertiliser replacement values) to calculate how much of the total $\mathrm{N}$ content of a livestock manure applied to their land will be available for the following crop. In England and Wales, these range from $10 \%$ for pig and cattle farmyard manures to $50 \%$ for pig slurry, with poultry manures predicted to have an NUE of 30\% (Anon., 2013), based largely on analyses of their readily available $\mathrm{N}$ content with some allowance for losses (mainly via nitrate leaching and ammonia volatilisation). In a review of manure $\mathrm{N}$ use efficiency throughout Europe, Webb et al. (2013) reported that NUEs are commonly based on the $\mathrm{N}$ estimated to be available during the first growing season only and that most countries predict short-term mineralisation using a simple $\mathrm{N}$ model of the annual relative decomposition rates of manure organic $\mathrm{N}$. They concluded that whilst longer term effects of organic $\mathrm{N}$ mineralisation are important and should be considered, this does not yet occur in the majority of EU Member States. .

One of the major challenges in determining the fertiliser value of manures is predicting how much of the manure organic $\mathrm{N}$ will mineralise both in the current and future growing seasons. Quantifying this is complicated by the presence of several $\mathrm{N}$ forms which differ between manure types, namely: mineral $\mathrm{N}$ (principally ammonium-N), readily mineralisable $\mathrm{N}$ (urea and uric acid for poultry manures) and more slowly mineralised organic compounds (e.g. lignin compounds). Indeed, Chadwick et al. (2000) showed considerable variation in the organic $\mathrm{N}$ content of fifty contrasting manure types (20 slurries, 20 FYM and 10 poultry manures), with cattle and pig slurry typically containing $29-35 \%$ of their total $\mathrm{N}$ content in organic forms, cattle and pig FYM 71\%, and broiler litter and layer manure $71 \%$ and $54 \%$, respectively. They also identified differences in the C:organic $\mathrm{N}$ ratios of the contrasting manure types, with cattle FYM typically having the highest ratio at 17:1, followed by cattle slurry and pig FYM at 14:1, pig slurry at 11:1, broiler litter at 9:1 and layer manure at 6:1. 
74 It is widely recognized that organic materials with low $\mathrm{C}: \mathrm{N}$ ratios tend to have higher rates

of mineralisation than those with higher C:N ratios (Floate, 1970; Serna \& Pomares, 1991; Aleef \& Nannipieri, 1995). Thus, organic N release is likely to vary according to manure type and C:organic $\mathrm{N}$ ratio. It is also dependent on the activities of decomposer organisms, which are themselves influenced by their physical environment, with temperature a key controlling factor (Watts et al., 2007; Whitmore, 2007).

Much of our understanding on the rate of mineralisation of manure $\mathrm{N}$ has been derived from short-term laboratory incubation or pot studies (e.g. Chadwick et al., 2000, Whitmore, 2007; Gil et al., 2011), which have often been complicated by the presence of variable amounts of mineral $\mathrm{N}$ at the outset of the study, related to the type of manure under consideration. The aim of this study was therefore to quantify the $\mathrm{N}$ mineralised from the organic fraction of farm manures under field conditions and to better understand the factors controlling the rate of $\mathrm{N}$ mineralisation. Additionally, the study aimed to derive simple predictive relationships to describe the rate of manure $\mathrm{N}$ mineralisation which could be used to improve predictions of crop available $\mathrm{N}$ supply and nitrate leaching losses following farm manure applications to land.

\section{Materials and methods}

\section{Experimental sites}

The study was undertaken from 1996 to 2001 at two experimental sites in the UK with contrasting climatic conditions (Table 1). Site 1 at Gleadthorpe in Nottinghamshire (SK593700), was on a loamy sand textured soil with a previous history of arable cropping and a low annual rainfall $(650 \mathrm{~mm})$. Site 2 at North Wyke in Devon (SX659983) was on a 
coarse sandy loam textured soil, also with a previous history of arable cropping, but in a high annual rainfall area $(1000 \mathrm{~mm})$.

\section{Treatments}

In spring 1996, nine manures (two cattle slurries, a pig slurry, two cattle FYMs, two pig FYMs, one broiler litter and one layer manure) were collected from commercial farms across England and Wales. The manures were selected to provide contrasting C:organic $\mathrm{N}$ ratios. Between 5 and 15 tonnes of solid manure and $25 \mathrm{~m}^{3}$ of slurry were collected.

The manures were 'stripped' of their ammonium-N content by cycles of wetting and drying over a period of 8 weeks, scaling up the approach used by Chadwick et al. (2000). This was achieved by spreading the solid manures on plastic sheets at depths of between 5 and $15 \mathrm{~cm}$, and after initial drying, the manures were re-wetted and turned periodically to encourage ammonia volatilisation. The slurries were held in lagoons constructed using straw bales and butyl liners. The slurries were allowed to settle and the supernatant (which contained high concentrations of ammonium-N) removed by pumping until only $c .50 \mathrm{~cm}$ of semi-solid manure remained. The dry matter of the supernatant was tested to ensure that solid manure organic matter was not being lost; in all cases the dry matter of the discarded liquid was less than $1 \%$. The semi-solid material was then spread out onto plastic sheets and treated in the same manner as the solid manures to encourage ammonia losses. The procedures were undertaken as quickly as practically possible to minimise organic $\mathrm{N}$ release during the 'stripping' process. The 'stripping' techniques were effective at reducing the readily available $\mathrm{N}$ content (mineral $\mathrm{N}$ plus uric acid $\mathrm{N}$ ) of the cattle, pig and poultry manures to < $5 \%,<10 \%$ and $<10 \%$ of the manure total $\mathrm{N}$ content, respectively. 
122 The nine 'stripped' manures were then applied by hand to the experimental sites, together with an untreated control (no manure application), at rates equivalent to $15-100$ t/ha dry solids, depending on the manure type, except for cattle slurry 1 where there was insufficient dry solids left after the stripping process and only 7-8 t/ha was applied. The high application rates were to ensure enough organic $\mathrm{N}$ was applied to be able to detect differences in mineralisation rates between treatments. At both sites, there were three replicates of each treatment in a randomised block design, with plots $3 \mathrm{~m} \times 10 \mathrm{~m}$ in size. Following land application, the manures were left on the surface for 48 hours to further encourage ammonia volatilisation losses, before being intimately mixed with the soil using a spading machine and rotavator prior to drilling with perennial ryegrass (Lolium perenne) in June 1996. No white clover was present on the plots at either site. Triplicate samples of the applied manures were analysed post-spreading for dry matter, nitrate-N, ammonium-N, uric-acid $\mathrm{N}$ (poultry manure only), total $\mathrm{N}$ and organic carbon (Anon, 1986), from which the final total $\mathrm{N}$ loadings were calculated (Table 2). The C:organic $\mathrm{N}$ ratios of the applied manures (Table 2) were in broad agreement with those of a survey of over 800 farm manures (Table 3; Defra, 2003), except for the broiler litter, which was higher than the survey results.

No $\mathrm{N}$ fertiliser was applied to the plots, however phosphate and potash fertiliser dressings were based on the site soil analysis results and applied at recommended rates, after making allowance for the phosphate and potash supplied in the farm manure applications (Anon., 2010). Both sites were cultivated and re-seeded during the course of the experiment to determine whether cultivation would stimulate further manure organic $\mathrm{N}$ release; this was carried out in July 1997 at site 1 (Gleadthorpe) and August 1999 at site 2 (North Wyke).

\section{Grass yield and nitrogen uptake}


145 Grass cuts were taken from site 1 (Gleadthorpe) in July 1996, September 1996, December 146 1996, April 1997, June 1997, June 1998, July 1999, June 2000 and July 2001, and at site 2

147 (North Wyke) in September 1996, November 1996, May 1997, July 1997, October 1997, 148 June 1998, August 1999, July 2000 and June 2001. At each cut, yield measurements were 149 made and grass samples analysed for total $\mathrm{N}$ and dry matter (Anon., 1986) so that crop $\mathrm{N}$ 150 uptakes could be calculated.

Nitrate leaching losses

Porous ceramic cups were installed at $90 \mathrm{~cm}$ depth at site 1 (Gleadthorpe) and 60cm depth at site 2 (North Wyke) on all plots (4 cups per plot) to measure nitrate-N leaching losses (Webster et al., 1993). Samples of soil water were collected after every $50 \mathrm{~mm}$ of drainage or two weeks, whichever occurred sooner, throughout winters 1996/97, 1997/98, 1998/99, 1999/2000 and 2000/01, and analysed for nitrate-N. Total nitrate-N leaching losses (kg/ha) were calculated using nitrate-N concentrations from the porous cup samples and estimates of drainage from the Irriguide water balance model (Bailey \& Spackman, 1996). Ammonium-N in the leachate samples was not measured as it is generally rapidly nitrified to nitrate-N.

\section{Estimation of manure organic $N$ mineralisation}

The amount of $\mathrm{N}$ mineralised from the applied organic manures was estimated by subtracting the sum of grass $\mathrm{N}$ uptakes $+\mathrm{N}$ leached on the untreated control from the sum of $\mathrm{N}$ uptakes $+\mathrm{N}$ leached on the manure treatments. This calculation assumed loss of $\mathrm{N}$ via denitrification or volatilisation was minimal, as nitrous oxide emissions from applied farm manures are typically $<1 \%$ of the total manure $\mathrm{N}$ applied (IPCC, 2006) and manures were incorporated into the soil thereby minimising further ammonia volatilisation losses. The initial readily available $\mathrm{N}$ content of the applied manures (i.e. that not removed by the 
'stripping' process, equivalent to $<10 \%$ of the total $\mathrm{N}$ content) was subtracted from the manure $\mathrm{N}$ uptake values, assuming 100\% efficiency of the readily available $\mathrm{N}$ applied.

Soil temperatures at $10 \mathrm{~cm}$ depth were monitored continuously at each site and soil moisture contents measured gravimetrically each month during the experiment. Manure $\mathrm{N}$ mineralisation rates were then related to thermal time, calculated as the cumulative day degrees (CDD) above 5 degrees after application, so that organic $\mathrm{N}$ 'decay' curves could be determined for each manure type.

\section{Statistical analysis}

Analysis of variance (ANOVA) was used to determine whether differences in plant $\mathrm{N}$ uptake, $\mathrm{N}$ leaching and calculated manure $\mathrm{N}$ mineralisation between the different manure types were statistically significant at $P<0.05$ (Genstat version 12; VSN International Ltd, 2010). The relationship between manure $\mathrm{N}$ mineralisation (expressed as a percentage of the manure organic $\mathrm{N}$ applied) and CDD was explored using regression analysis, and the slopes of the relationships derived for the different manure types compared using $95 \%$ confidence intervals.

\section{Results}

\section{Grass N uptake}

During the 12 months following land application (June 1996 to June 1997), grass N uptake net of the untreated control at Gleadthorpe (Site 1) was greatest on the pig slurry treatment at $265 \mathrm{~kg} / \mathrm{ha} \mathrm{N}$ and smallest on the pig FYM-2 treatment at $23 \mathrm{~kg} / \mathrm{ha} \mathrm{N}(P<0.05)$. This equated to $46 \%$ and $3 \%$ of the organic $\mathrm{N}$ applied, respectively (Figure 1). Following cultivation of the site in July 1997, grass $\mathrm{N}$ uptake on all the manure treatments was greater than on the untreated control in June 1998, July 1999 and June $2000(P<0.05)$. Grass N 
uptake post cultivation was equivalent to a mean of $5 \%$ (range $3-7 \%$ ) of the organic $\mathrm{N}$ applied (Figure 1). However, by July 2001, grass N uptake on the manure treatments was the same $(P>0.05)$ as on the untreated control, indicating that manure organic $\mathrm{N}$ mineralisation had effectively stopped (had dropped to un-detectable levels, as measured by grass $\mathrm{N}$ uptake) in the fifth year after application.

Grass N uptake net of the untreated control at North Wyke (Site 2) was generally higher than at Gleadthorpe, especially in the first 3 months after application. The greatest $(P<0.05)$ $\mathrm{N}$ uptake was measured on the pig slurry and layer manure treatments $(68 \%$ and $61 \%$ of organic $\mathrm{N}$ applied, respectively), and lowest on the cattle slurry-1 treatment (9\% of organic $\mathrm{N}$ applied); Figure 2). $\mathrm{N}$ uptake data from the grass cuts taken in October 1997, June 1998 and August 1999 were not different from the untreated control $(P>0.05)$, indicating that mineralisation of the manure organic $\mathrm{N}$ had effectively ceased $c .13$ months after the initial application (Figure 2). Moreover, following cultivation in August 1999, grass $\mathrm{N}$ uptakes in July 2000 and June 2001 on the manure treatments were not different from those on the untreated control $(P>0.05)$, indicating that cultivation had not stimulated further manure organic $\mathrm{N}$ release.

\section{Nitrate leaching losses}

In the first winter following application (1996/97), rainfall at Gleadthorpe and North Wyke was $85 \%$ and $75 \%$ of the long-term average (Table 4), respectively. The low rainfall, coupled with large moisture deficits created by the grass cover in the dry summer of 1996 , meant that drainage did not begin at both sites until early December 1996. Nitrate-N leaching losses at Gleadthorpe were less than $1 \%$ of organic $\mathrm{N}$ applied on the cattle / pig FYM and cattle slurry treatments, and $c .3 \%$ on the pig slurry, broiler litter and layer manure treatments (Table 5). At North Wyke, leaching losses were comparable to those at 
217 Gleadthorpe, except on the pig slurry treatment where losses were equivalent to $10 \%$ of the applied organic $\mathrm{N}$ (Table 5).

219 In subsequent years (1997/98 and 1998/99), relatively wet summers meant that drainage 220 began in late October/early November at both sites. In the second winter (1997/98), nitrate-

$221 \mathrm{~N}$ leaching losses at Gleadthorpe increased to $10 \%$ and $12 \%$ of the applied organic $\mathrm{N}$ on the cattle FYM -1 and cattle slurry -1 treatments, respectively (Table 5). At North Wyke, leaching losses on all the manure treatments were less than $1 \%$ of the organic $\mathrm{N}$ applied and not significantly different from the untreated control $(P>0.05)$. This is in agreement with the grass $\mathrm{N}$ uptake results, confirming that mineralisation of the manure organic $\mathrm{N}$ had effectively ceased at this site $c .13$ months after the initial manure application. Drainage volumes were greatest in winter 2000/01, reflecting overwinter rainfall c.50\% and c.40\% greater than the long-term average at Gleadthorpe and North Wyke, respectively (Table 4). However, in winters 1998/99, 1999/2000 and 2000/01, nitrate leaching losses on the manure treatments at both sites were similar to those on the untreated control $(P>0.05)$, indicating that released organic $\mathrm{N}$ was not contributing to the $\mathrm{N}$ leached.

\section{Manure organic $N$ mineralisation}

The estimated amount of $\mathrm{N}$ mineralised from the applied organic manures, expressed as a percentage of the organic $\mathrm{N}$ applied was related to thermal time after application (expressed as cumulative day degrees above $5^{\circ} \mathrm{C}$; CDD). At Gleadthorpe, the relationship (Figure 3a) could be divided into three phases: phase 1 (up to $c .1300$ CDD) when grass growth was limited by the dry summer weather after the site was established (total rainfall $89 \mathrm{~mm}$ in 3 months), phase 2 when plant $\mathrm{N}$ uptake proceeded rapidly (c.1300-2200 CDD) during autumn 1996 and spring/summer 1997, and Phase 3 (>c.2200 CDD) when mineralisation had slowed. At North Wyke, the better grass growing conditions immediately after the ryegrass 
established (total rainfall $122 \mathrm{~mm}$ in 3 months) meant that crop uptake of the mineralised $\mathrm{N}$ was less limited by drought (Figure 3b), but after c. 2300 CDD, mineralisation of the applied manures had effectively ceased at the site.

Based on visual inspection of the data in Figure $3 a$ and $b$, two phases of mineralisation were identified: a rapid phase which continued up to $2300 \mathrm{CDD}$, and a slower phase when thermal time exceeded 2300 CDD.

Across both sites, the greatest amounts of $\mathrm{N}$ mineralisation up to $2300 \mathrm{CDD}$ were from the pig slurry (52\% and 67\% of organic N applied at Gleadthorpe and North Wyke, respectively) and layer manure (36\% and 60\%, of organic N applied at Gleadthorpe and North Wyke, respectively) treatments. The lowest amounts were from the cattle FYM-2 and pig FYM-2 treatments at Gleadthorpe (4\% of organic $\mathrm{N}$ applied for both treatments), and from the cattle slurry-2 treatment at North Wyke (10\% of organic N applied). Up to 2300 CDD, manure organic $\mathrm{N}$ mineralisation was linearly related to thermal time $\left(P<0.01\right.$ and $\left.\mathrm{r}^{2}>70 \%\right)$, but varied with manure type (Table 6). Comparison of 95\% confidence intervals for the slope of each relationship showed that the relationships fell into 2 broad groups at each site (Figure 4a,b). The first group included pig slurry and layer manure which had a higher rate of mineralisation (0.014 - $0.028 \%$ mineralised/CDD), compared with the second group which included cattle/pig FYM and cattle slurry that had lower rates of mineralisation (0.002-0.014 $\%$ mineralised/CDD). Broiler litter fell midway between these two groups (0.01-0.018 $\%$ mineralised/CDD).

The amounts of $\mathrm{N}$ mineralised by the two manure type groups (FYM/cattle slurry and pig slurry/poultry manure) were used to derive 'standard' organic $\mathrm{N}$ release functions. This was initially done for each site separately, as CDDs were different at the two sites. The broiler 
litter results were excluded from the relationships, because of their atypically high C:organic $\mathrm{N}$ ratio (at 15:1; Table 2). Again there were significant differences between the slopes of the two manure type groups (based on a comparison of the $95 \%$ confidence intervals), but not between the two sites (Table 7). Consequently, the results from the two sites were pooled in order to derive 'generic' organic $\mathrm{N}$ release functions for future modelling purposes (Figure 5). These were:

\section{1}

For cattle/pig FYM and cattle slurry $(\mathrm{C}$ : organic N 10-21; mean =14):

$$
\% \text { organic } \mathrm{N} \text { mineralised }=0.0076 / \mathrm{CDD} \text { up to } 2300 \mathrm{CDD}
$$

Relationship between manure organic $N$ mineralisation and thermal time over 2300 CDD

At Gleadthorpe, mineralisation of the organic manures continued to occur, albeit at a much slower rate at CDD>2300. This may have been due to the stimulation of mineralisation following cultivations at c.2200 CDD. During this second phase, the amount of $\mathrm{N}$ mineralised (expressed as a percentage of the manure organic $\mathrm{N}$ applied) was again linearly related to thermal time $(P=0.05)$, with similar slopes for both manure type groups (Table starting value (i.e. the intercept) was higher for the pig slurry and layer manure group than the cattle/pig FYM and cattle slurry group. At North Wyke, mineralisation effectively ceased (was undetectable) at $>2300 \mathrm{CDD}$ for both manure type groups (Table 7), and was not stimulated by cultivation in August 1999.

As with the period up to $c .2300 \mathrm{CDD}$, results from the two sites were combined. These were: 
289 For pig slurry and poultry manure:

$$
\% \text { organic } \mathrm{N} \text { mineralised }=0.0001 / \mathrm{CDD}
$$

291 Overall, differences in net $\mathrm{N}$ mineralisation between the two manure type groups largely occurred in the period up to $2300 \mathrm{CDD}$. Combining equations 1-4 gave the following 'generic' functions, suitable for modelling purposes:

Prediction of \% organic N mineralised from cattle/pig FYM and cattle slurry:

$$
\% \text { organic } \mathrm{N} \text { mineralised }=(0.0076 * 2300)+[(\mathrm{CDD}-2300) * 0.0004)]
$$

Prediction of $\%$ organic $\mathrm{N}$ mineralised from pig slurry \& poultry manure:

$$
\% \text { organic } \mathrm{N} \text { mineralised }=(0.0076 * 2300)+[(\mathrm{CDD}-2300) * 0.0004)]
$$

\section{Discussion}

The crop available $\mathrm{N}$ supply from livestock manure applications is not limited to its readily available (mineral) $\mathrm{N}$ content. Mineralisation of the organic $\mathrm{N}$ fraction, both in the year of application and subsequent seasons can also contribute significant amounts of $\mathrm{N}$, particularly where manures are repeatedly applied to the same field (Whitmore \& Schröder, 1996; Schröder et al., 2007). Indeed, Schröder et al. (2007) showed that grass dry matter yields responded positively to both current manure applications (cattle slurry and FYM) and applications made in previous seasons (4 annual applications), whereas mineral fertiliser $\mathrm{N}$ only affected yields in the year of application. Both the mineral and organic $\mathrm{N}$ supply from the applied manures was considered by Schröder et al. (2007), whereas the work described here assessed the $\mathrm{N}$ contribution derived almost entirely from the organic fraction of the applied manures, i.e. from mineralisation. 
310 There has been much research effort into understanding, quantifying and modelling the 311 factors which affect the mineralisation of soil organic nitrogen derived from a variety of 312 sources (Jarvis et al., 1996). As a microbially mediated process it is highly dependent on 313 soil temperature and moisture (Whitmore, 2007; Watts et al., 2010), as well as the 314 composition of the applied materials (e.g. C:N ratio, lignin content; Chadwick et al., 2000; 315 Pu et al., 2012). The amount of $\mathrm{N}$ released can also differ in response to soil texture, with 316 greater protection of organic matter and consequently lower rates of mineralisation in clay 317 soils (Hassink, 1994). A number of studies have used thermal time to predict $\mathrm{N}$ 318 mineralisation. For example, Douglas \& Rickman (1992) simulated crop residue 319 decomposition as a function of thermal time and observed a rapid decomposition rate up to $1000 \mathrm{CDD}$ which was related to the $\mathrm{N}$ content of the residue, followed by a slower phase at $>1000 \mathrm{CDD}$, which was regulated by the lignin content of the crop residue. Clough et al. (1998) measured soil organic matter mineralisation rates on a range of grassland soils and found that mineralisation was linearly related to cumulative soil temperatures above $0{ }^{\circ} \mathrm{C}$. Similarly, Honeycutt \& Potaro (1990) found that soil thermal units (CDD) were useful in predicting net mineralisation. The combination of a release curve approach and CDD data, although a relatively crude approach, is attractive in its simplicity and has been shown to improve the accuracy of predicting manure N availability (Castellanos \& Pratt, 1981; 328 Klausner et al., 1994).

In this study, manure organic $\mathrm{N}$ mineralisation was related to $\mathrm{CDD}$ (above $5^{\circ} \mathrm{C}$ ) in two phases; an initial phase up to 2300 CDD (c.18 months under UK climatic conditions) where mineralisation proceeded at rates ranging between $0.005-0.027 \%$ mineralised/CDD, and a slower phase at $>2300 \mathrm{CDD}$, where rates were negligible at $<0.001 \%$ mineralised/CDD.

333 There was no difference between soil types, both being light-textured, although net $\mathrm{N}$ mineralisation dropped to undetectable levels much earlier (after 18-24 months) on the 
slightly heavier textured soil in the high rainfall area (North Wyke), compared to the site in the low rainfall area and lighter textured soil (Gleadthorpe), where mineralisation of the manure organic $\mathrm{N}$ was detectable up to 4 years after application. Gil et al. (2010) also observed that mineralisation of compost applied to soil in a laboratory incubation study occurred in two phases, an initial rapid phase during the first year of application, where the relationship between $\% \mathrm{~N}$ mineralised and time was best described by an exponential function, and a slower phase in the second year which was described by a 'special model', with more parameters. They concluded that this suggested the organic $\mathrm{N}$ in the compost consisted of two fractions with different degrees of stability - labile organic $\mathrm{N}$ and resistant organic N. Schröder et al. (2007) in a field study also observed that the residual N effect of manure applications was greatest in the year of application and 'faded away' afterwards.

Schröder et al. (2007) found no clear distinction between the two contrasting manure types studied (cattle FYM and cattle slurry); however the C:organic $\mathrm{N}$ ratios of the manures were very similar (in the range 14.8-15.8). In this current study, the greater amount of $\mathrm{N}$ mineralised from the pig slurry and layer manure compared with the cattle slurry \& cattle/pig FYMs was most likely a reflection of differences in the C:organic $\mathrm{N}$ ratios of the manure types. Pig slurry and layer manure had lower C:organic N ratios (range 9-12:1) than the cattle slurry and straw-based FYMs (range 10-21:1). Chadwick et al. (2000) also showed that the amount of $\mathrm{N}$ mineralised from a range of farm manures in a laboratory incubation study was inversely related to the $\mathrm{C}$ :organic $\mathrm{N}$ ratio of the manures $\left(P<0.01 ; \mathrm{r}^{2}=0.63\right)$. Similarly, Serna \& Pomares (1991) demonstrated a significant relationship between animal manure $C: N$ ratios and $\mathrm{N}$ mineralisation $\left(\mathrm{r}^{2}=-48 \%\right)$, and Floate (1970) showed a weak relationship between the $\mathrm{C}: \mathrm{N}$ ratio of sheep faeces and $\mathrm{N}$ mineralised $\left(\mathrm{r}^{2}=-31 \%\right)$. Moreover, Eghball et al. (2002) estimated that mineralized organic $\mathrm{N}$ availability was highest in poultry/broiler manures (55\%) and in lowest in dairy (21\%) and composted (18\%) manures 
in the first year of a laboratory incubation study. However, Castellanos \& Pratt (1981) found no relationship between manure $\mathrm{C}: \mathrm{N}$ ratios and $\mathrm{N}$ mineralised for a range of stored and fresh animal manures.

The results also clearly indicate the importance of taking into account mineralisation when calculating manure $\mathrm{N}$ efficiency coefficients, particularly where manures are repeatedly applied to the same field. For pig slurry and layer manure up to $70 \%$ of the organic $\mathrm{N}$ was mineralised, predominantly in the first 18 months after application, but continuing for up to 4 years on the lighter textured soil, compared with $10-30 \%$ mineralisation from the cattle slurry and cattle/pig FYMs. However, although the manure organic $\mathrm{N}$ mineralisation was greatest for the pig slurry, giving rise to higher manure $\mathrm{N}$ efficiencies in the first 18 months, the longer-term residual effect of a manure application is considered to be greater for FYM, as at typical application rates (i.e. rates equivalent to $250 \mathrm{~kg} / \mathrm{ha}$ total $\mathrm{N}$ ) this supplies more organic N than slurry (Schröder et al., 2005; Van Dijk \& ten Berge, 2009). Importantly, $100 \%$ manure organic $\mathrm{N}$ mineralisation was never achieved, with the remaining manure organic $\mathrm{N}$ most likely contributing to the very stable soil organic matter (humus) pool.

\section{Conclusions}

376 Mineralisation of the organic $\mathrm{N}$ fraction of farm manures, both in the year of application and subsequent seasons can contribute significant amounts of crop available $\mathrm{N}$, which should be taken into account in fertiliser recommendations in order to reduce losses to the wider environment. The amount of $\mathrm{N}$ mineralised was seen to be dependent on the manure C:organic $\mathrm{N}$ ratio, with greater mineralisation at ratios ranging from 9-12:1 (pig slurry and poultry manures) compared to cattle slurries and straw-based FYMs, with C:organic $\mathrm{N}$ ratios in the range 10-21:1. Temperature after application was also important and simple relationships were derived for each of these groups of manures for the amount of $\mathrm{N}$ 
mineralised and thermal time. The relationships derived provide a useful tool for predicting both the amount and timing of manure $\mathrm{N}$ release, with important implications for both crop $\mathrm{N}$ uptake and leaching risk. Indeed the functions have been recently incorporated into a decision support tool (MANNER-NPK; Nicholson et al., 2013), which quantifies manure crop available nutrient supply, and is designed to support the better use of manure nutrients to enable both savings in fertilisers and a reduction in environmental impacts.

\section{Acknowledgements}

This study was funded by the UK Department for the Environment and Rural Affairs, project NT2106. The authors wish to thank Gail Bennett (ADAS) and Chris John (North Wyke) for management and sampling of the experimental sites.

\section{References}

Aleef, K \& Nannipieri, P. 1995. Methods in Applied Soil Microbiology and Biochemistry. Academic Press, London

Anon. 1986. The Analysis of Agricultural Materials. Reference Book 427. Ministry of Agriculutre, Fisheries and Food.

Anon. 2010. The Fertiliser Manual (RB209). $8^{\text {th }}$ Edition. www.defra.gov.uk

Anon. 2013. Guidance on complying with the rules for Nitrate Vulnerable Zones in England for 2013 to 2016. www.gov.uk/nitrate-vulnerable-zones.

Bailey R.J. \& Spackman, E. 1996. A model for estimating soil moisture changes as an aid to irrigation scheduling and crop water-use studies: I Operational details and description. Soil Use and Management, 12, 122-129. 
405 Chadwick, D.R., John, F., Pain, B.F., Chambers, B.J. \&Williams, J. 2000. Plant uptake of 406 nitrogen from the organic nitrogen fraction of animal manures: a laboratory experiment. $407 \quad$ Journal of Agricultural Science, 134, 159-168.

408

409

410

411

412

413

414

415

416

417

418

419

420

421

422

423

424

425

426

427

Castellanos, J.Z. \& Pratt, P.F. 1981. Mineralisation of manure nitrogen - correlation with laboratory indexes. Soil Science Society of America Journal, 44, 354-357.

Chambers, B.J., Smith, K.A. \& van der Weerden, T.J. 1997. Ammonia emissions following the land spreading of solid manures. In: Gaseous Nitrogen Emissions from Grassland (Eds. S.C. Jarvis and B.F. Pain), CAB International, UK, pp 275-280.

Clough, T.J., Jarvis, S.C. \& Hatch, D.J. 1998. Relationships between soil thermal units, nitrogen mineralisation and dry matter production in pastures. Soil Use and Management, 14, 65-69.

Defra, 2003. Manure Analysis Database (MANDE). Final report to Defra for project NT2006. www.defra.gov.uk.

Douglas, C.L., Jr. \& Rickman, R.W. 1992. Estimating crop residue decomposition from air temperature, initial nitrogen content and residue placement. Soil Science Society of America Journal, 56, 272-278.

Eghball, B., Wienhold, B.J., Gilley, J.E. \& Eigenberg, R.A. 2002. Mineralization of manure nutrients. Journal of Soil And Water Conservation, 57, 470-473.

Floate, M.S. 1970. Decomposition of organic materials from hill soils and pastures II. Comparative studies on carbon, nitrogen and phosphorus from plant materials and sheep faeces. Soil Biology and Biochemistry, 2, 173-185.

Gil, M. V., Carballo, M. T. \& Calvo, L. F. 2011. Modelling N mineralization from bovine manure and sewage sludge composts. Bioresource Technology, 102, 863-871. 
Hassink, J. 1994. Effects of soil texture and grassland management on soil organic C and N and rates of C and N mineralisation. Soil Biology and Biochemistry, 26, 1221-1231.

Honeycutt, C.W. \& Potaro, L.J. 1990. Field evaluation of heat units for predicting crop residue carbon and nitrogen mineralisation. Plant and Soil, 125, 213-220.

IPCC 2006. Guidelines for National Greenhouse Gas Inventories. Volume 4, Agriculture, Forestry and Other Land Use. IGES, Japan.

Jarvis, S.C. \& Pain, B.F. 1990. Ammonia volatilisation from agricultural land. The Fertiliser Society. Proceedings No.298. Greenhill House, Thorpe Wood, Peterborough.

Jarvis, S.C., Stockdale, E.A., Shepherd, M.A. \& Powlson, D.S. 1996. Nitrogen mineralisation in temperate agricultural soils: processes and measurement. Advances in Agronomy, 57, 187-237.

Klausner, S.D., Kanneganti, V.R. \& Bouldin, D.R. 1994. An approach for estimating a decay series for organic nitrogen in animal manures. Agronomy Journal, 86, 897-903.

Nicholson, F.A., Anthony, S. \& Chambers, B.J. 2008. The National Inventory and Map of Livestock Manure Loadings to Agricultural Land: MANURE-GIS. Final Report to Defra for project WQ0103. Ww.defra.gov.uk

Nicholson, F.A., Bhogal, A., Chadwick, D., Gill, E., Gooday, R.D., Lord, E., Misselbrook, T., Rollett, A.J., Sagoo, E., Smith, K.A., Thorman, R.E., Williams, J.R. \& Chambers, B.J. 2013. An enhanced software tool to support better use of manure nutrients: MANNERNPK. Soil Use and Management, 29, 473-484.

Pu, G., Bell, M., Barry, G. \& Want, P. 2012. Estimating mineralisation of organic nitrogen from biosolids and other organic wastes applied to soils in subtropical Australia. Soil Research, 50 (2), 91-104. 
Schröder, J.J., Jansen, A.G. \& Hilhorst, G.J. 2005. Long-term nitrogen supply from cattle slurry. Soil Use and Management, 21, 196-204.

Schröder, J.J., Uenk, D. \& Hilhorst, G.J. 2007. Long-term nitrogen fertiliser replacement value of cattle manures applied to cut grassland. Plant and Soil, 299, 83-99.

Serna, M.D. \& Pomares, F. 1991. Comparison of biological and chemical methods to predict nitrogen mineralisation in animal wastes. Biology and Soil Fertility, 12, 89-94.

SI, 2008. The Nitrate Pollution Prevention Regulations 2008. Statutory Instrument 2008 No 2349. http://www.opsi.gov.uk/si/si2008/uksi_20082349_en_1 (accessed 27/4/10)

Unwin, R.J., Shepherd, M.A. \& Smith, K.A. 1991. Controls on manure and sludge applications to limit nitrate leaching. Does the evidence justify the restrictions which are being proposed? In: Treatment and Use of Sewage Sludge and Liquid Agricultural Wastes (ed. P.L.Hermite). Elsevier Applied Science, London. pp 261-270.

Van Dijk, W. \& ten Berge, H. 2009. Agricultural Nitrogen Use in Selected EU Countries. Applied Plant Research, Wageningen. PPO Publication no. 382.

Watts, D. B., Torbert, H. A. \& Prior, S. A. 2007. Mineralization of nitrogen in soils amended with dairy manure as affected by wetting/drying cycles. Communications in Soil Science and Plant Analysis, 38, 2103-2116.

Watts, D.B., Torbert, H.A. \& Prior, S.A. 2010. Soil property and landscape position effects on seasonal nitrogen mineralization of composted dairy manure. Soil Science, 175, 27 35.

Webb, J.; Sörensen, P.; Velthof, G.L.; Amon, B.; Pinto, M.; Rodhe, L.; Salomon, E.; Hutchings, N.; Burczyk, J.; Reid, J.E. 2013. Chapter Seven-An Assessment of the 
473 Variation of Manure Nitrogen Efficiency throughout Europe and an Appraisal of Means

$474 \quad$ to Increase Manure-N Efficiency. Advances in Agronomy 119, 371-442

475 Webster, C.P., Shepherd, M.A., Goulding, K.W.T. \& Lord, E.I. 1993. Comparison of 476 methods for measuring the leaching of mineral nitrogen from arable land. Journal of $477 \quad$ Soil Science 44, 46-62.

478 Whitmore, A.P. \& Schröder, J.J. 1996. Modelling the change in soil organic C and N and 479 the mineralisation of $\mathrm{N}$ from soil in response to applications of slurry manure. Plant $480 \quad$ and Soil, 184, 185-194.

481 Whitmore, A. P. 2007. Determination of the mineralization of nitrogen from composted 482 chicken manure as affected by temperature. Nutrient Cycling in Agroecosystems, 77, $483 \quad 225-232$ 
487

488 Table 1. Soil type, cropping and average annual rainfall.

489 Table 2. Total $\mathrm{N}$ loadings and C: organic $\mathrm{N}$ ratios of the manures applied at each field site.

490 Table 3. Carbon and nitrogen composition of a range of farm manures. Average data taken 491 from the Defra Manure Analysis Database (Defra, 2003).

492 Table 4. Overwinter rainfall (1st September to 31st March) and drainage (mm).

493 Table 5. Total nitrate-N leached expressed as a \% of the organic $\mathrm{N}$ applied.

494 Table 6. Relationship between manure organic $\mathrm{N}$ mineralisation (\% organic $\mathrm{N}$ applied) and 495 thermal time (up to 2300 CDD). GT = Gleadthorpe, NW = North Wyke

496 Table 7. Relationships between manure organic $\mathrm{N}$ mineralisation (\% organic $\mathrm{N}$ applied) 497 and thermal time (CDD above $5{ }^{\circ} \mathrm{C}$ ) at Gleadthorpe (GT) and North Wyke (NW). 
500

501 Figure 1. Grass $\mathrm{N}$ uptake at Gleadthorpe, expressed as a \% of the organic N applied

502 Figure 2. Grass $\mathrm{N}$ uptake at North Wyke expressed as a \% of the organic $\mathrm{N}$ applied

503 Figure 3. Manure organic $\mathrm{N}$ mineralisation in relationship to thermal time (cumulative day

504 degrees above $5^{\circ} \mathrm{C}$; CDD) at a) Gleadthorpe and b) North Wyke

505 Figure 4. Confidence intervals for the slope of the relationship between manure organic $\mathrm{N}$

506 mineralisation and thermal time at a) Gleadthorpe and b) North Wyke.

507 Figure 5. Relationship between $\%$ manure organic $\mathrm{N}$ mineralised and thermal time for the 508 two manure groups up to 2300 CDD.

509

510

511

512

513 
516 Table 1. Soil type, cropping and average annual rainfall.

\begin{tabular}{cccccc}
\hline Site & Topsoil texture & Average annual & Topsoil total & Topsoil organic & Topsoil \\
& $(\%$ clay $)$ & rainfall $(\mathrm{mm})^{1}$ & $\mathrm{~N}(\%)$ & matter $(\%)$ & C: N ratio \\
\hline Gleadthorpe & Loamy sand $(9 \%)$ & 650 & 0.04 & 1.7 & $25: 1$ \\
North Wyke & Sandy loam $(18 \%)$ & 1000 & 0.08 & 1.8 & $13: 1$
\end{tabular}

$517 \quad 130$ year average

518 
519 Table 2. Total $\mathrm{N}$ loadings and $\mathrm{C}$ : organic $\mathrm{N}$ ratios of the manures applied at each field site; standard errors shown in brackets.

\begin{tabular}{ccccc}
\hline Treatment & \multicolumn{2}{c}{ Total N loading (kg/ha) } & C: organic N ratio \\
\cline { 2 - 5 } & Gleadthorpe & North Wyke & Gleadthorpe & North Wyke \\
\hline Cattle FYM 1 & $526(80)$ & $632(51)$ & $21.2(2.3)$ & $19.5(4.4)$ \\
Cattle FYM 2 & $901(44)$ & $848(36)$ & $11.0(0.3)$ & $11.0(0.3)$ \\
Pig FYM 1 & $863(98)$ & $1031(37)$ & $14.4(2.6)$ & $12.2(1.0)$ \\
Pig FYM 2 & $794(89)$ & $861(100)$ & $9.8(2.0)$ & $8.1(0.2)$ \\
Cattle slurry 1 & $172(15)$ & $364(6)$ & $13.0(1.2)$ & $10.3(0.3)$ \\
Cattle slurry 2 & $676(52)$ & $724(8)$ & $14.3(2.1)$ & $13.3(0.7)$ \\
Pig slurry & $577(28)$ & $543(36)$ & $11.8(0.8)$ & $11.3(5.0)$ \\
Broiler litter & $674(46)$ & $364(19)$ & $15.4(0.6)$ & $14.8(1.8)$ \\
& & & & \\
Layer manure & $659(67)$ & $638(46)$ & $8.8(0.8)$ & $9.7(1.2)$ \\
\hline
\end{tabular}

521

522

523 
524 Table 3. Carbon and nitrogen composition of a range of farm manures. Average data taken

525 from the Defra Manure Analysis Database (Defra, 2003); standard errors shown in brackets.

\begin{tabular}{lccccc}
\hline Manure & $\begin{array}{c}\text { Sample } \\
\text { number }\end{array}$ & $\begin{array}{c}\text { Dry matter } \\
(\%)\end{array}$ & $\begin{array}{c}\text { Organic C } \\
(\% \mathrm{dm})\end{array}$ & $\begin{array}{c}\text { Organic N } \\
(\% \mathrm{dm})^{2}\end{array}$ & C: organic $\mathrm{N}^{3}$ \\
\hline Cattle FYM & $230-263$ & $23(0.5)$ & $33(0.4)$ & $2.3(0.1)$ & 14.3 \\
Cattle slurry & $89-179$ & $8.5(0.2)$ & $34(0.4)$ & $2.5(0.1)$ & 13.6 \\
Pig FYM & $35-39$ & $26(1.4)$ & $32(1.1)$ & $2.3(0.2)$ & 13.9 \\
Pig slurry & $17-75$ & $3.7(0.5)$ & $33(1.9)$ & $3.5(0.3)$ & 9.4 \\
Poultry litter & $28-40$ & $60(2.1)$ & $33(1.0)$ & $3.4(0.2)$ & 9.7 \\
Layer manure & $87-95$ & $35(1.1)$ & $28(0.5)$ & $2.9(0.2)$ & 9.7
\end{tabular}

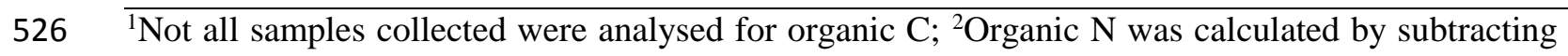

527 the average readily available $\mathrm{N}$ content (ammonium- $\mathrm{N}+$ nitrate- $\mathrm{N}+$ uric acid $\mathrm{N}$ ) from the average

528 total $\mathrm{N}$ content; ${ }^{3} \mathrm{Calculated}$ from the reported average $\mathrm{C}$ and organic $\mathrm{N}$ contents. ${ }^{4} \mathrm{~A}$ combination of

529 broiler and turkey litters 
531 Table 4. Overwinter rainfall (1st September to 31st March) and drainage (mm).

\begin{tabular}{lcccc}
\hline Site & \multicolumn{2}{c}{ Gleadthorpe } & \multicolumn{2}{c}{ North Wyke } \\
\cline { 2 - 5 } & Rainfall & Drainage & Rainfall & Drainage \\
\hline Average Annual & 364 & - & 756 & - \\
$96 / 97$ & 316 & 85 & 584 & 173 \\
$97 / 98$ & 322 & 148 & 540 & 189 \\
$98 / 99$ & 407 & 124 & 646 & 423 \\
$99 / 00$ & 311 & 123 & 740 & 593 \\
$00 / 01$ & 522 & 278 & 1078 & 688 \\
\hline
\end{tabular}

532

533 
534 Table 5. Total nitrate-N leached in winters 1996/97 and 1997/98 expressed as a \% of the 535 organic $\mathrm{N}$ applied.

\begin{tabular}{|c|c|c|c|}
\hline \multirow[t]{2}{*}{ Treatment } & \multicolumn{2}{|c|}{$1996 / 97$} & \multirow{2}{*}{$\begin{array}{c}1997 / 98 \\
\text { GT }\end{array}$} \\
\hline & GT & NW & \\
\hline Cattle FYM1 & 0.8 & 0.3 & 10.4 \\
\hline Cattle FYM2 & 0.1 & 0.3 & 0.7 \\
\hline Pig FYM1 & 1.1 & 2.6 & 0.7 \\
\hline Pig FYM2 & 0.7 & 0.3 & 0.1 \\
\hline Cattle slurry 1 & 0.1 & 0.2 & 13.0 \\
\hline Cattle slurry 2 & 0.2 & 0.3 & 0.6 \\
\hline Pig slurry & 2.7 & 10.0 & 1.1 \\
\hline Broiler litter & 2.5 & 0.3 & 3.0 \\
\hline Layer manure & 3.4 & 2.4 & 4.6 \\
\hline
\end{tabular}

536 Note: N leaching on the treated plots was identical to the untreated control at North Wyke 537 in 1997/98 and at both sites in 1998/99, 1999/00 and 2000/01. 
539 Table 6. Relationship between manure organic $\mathrm{N}$ mineralisation (\% organic $\mathrm{N}$ applied) and 540 thermal time (up to 2300 CDD). GT = Gleadthorpe, NW = North Wyke

\begin{tabular}{|c|c|c|c|c|c|c|c|c|}
\hline \multirow[t]{2}{*}{ Treatment } & \multicolumn{2}{|c|}{$\mathrm{r}^{2}$} & \multicolumn{2}{|c|}{$P$} & \multicolumn{2}{|c|}{ Slope } & \multicolumn{2}{|c|}{$95 \% \mathrm{CI}^{*}$} \\
\hline & GT & NW & GT & NW & GT & NW & GT & NW \\
\hline Cattle FYM1 & 0.85 & 0.81 & $<0.001$ & 0.002 & 0.005 & 0.014 & 0.0013 & 0.0055 \\
\hline Cattle FYM2 & 0.76 & 0.86 & $<0.001$ & 0.001 & 0.002 & 0.010 & 0.0004 & 0.0031 \\
\hline Pig FYM1 & 0.77 & 0.89 & 0.001 & 0.001 & 0.007 & 0.014 & 0.0028 & 0.0038 \\
\hline Pig FYM2 & 0.73 & 0.89 & 0.008 & 0.001 & 0.002 & 0.009 & 0.0012 & 0.0024 \\
\hline Cattle slurry 1 & 0.87 & 0.87 & $<0.001$ & 0.001 & 0.007 & 0.012 & 0.0022 & 0.0036 \\
\hline Cattle slurry 2 & 0.90 & 0.90 & $<0.001$ & $<0.001$ & 0.005 & 0.004 & 0.0011 & 0.0012 \\
\hline Pig slurry & 0.88 & 0.95 & $<0.001$ & $<0.001$ & 0.021 & 0.028 & 0.0051 & 0.0051 \\
\hline Broiler litter & 0.93 & 0.95 & $<0.001$ & $<0.001$ & 0.010 & 0.018 & 0.0017 & 0.0031 \\
\hline Layer manure & 0.85 & 0.97 & $<0.001$ & $<0.001$ & 0.014 & 0.027 & 0.0039 & 0.0034 \\
\hline
\end{tabular}

542 df) and 2.776 for North Wyke (4 df) 

and thermal time (CDD above $5{ }^{\circ} \mathrm{C}$ ) at Gleadthorpe (GT) and North Wyke (NW).

\begin{tabular}{|c|c|c|c|c|c|c|c|c|}
\hline \multirow[t]{2}{*}{ Treatment } & \multicolumn{2}{|c|}{$r^{2}$} & \multicolumn{2}{|c|}{$P$} & \multicolumn{2}{|c|}{ Slope } & \multicolumn{2}{|c|}{$95 \%$ CI } \\
\hline & GT & NW & GT & NW & GT & NW & GT & NW \\
\hline
\end{tabular}

\begin{tabular}{|c|c|c|c|c|c|c|c|c|}
\hline \multicolumn{9}{|c|}{ Relationship up to 2300 CDD: } \\
\hline FYM \& cattle & 0.89 & 0.86 & $<0.001$ & $<0.001$ & 0.005 & 0.01 & 0.001 & 0.003 \\
\hline \multicolumn{9}{|l|}{ slurry } \\
\hline Pig slurry \& layer & 0.87 & 0.96 & $<0.001$ & $<0.001$ & 0.017 & 0.027 & 0.004 & 0.004 \\
\hline
\end{tabular}

Relationship > 2300 CDD:

FYM \& cattle

$\begin{array}{lll}0.67 & 0.55 \quad 0.05\end{array}$

$\begin{array}{lll}0.10 & 0.0011 & 0.0002\end{array}$

13.1

26.3

slurry

(NS)

Pig slurry \& layer

$\begin{array}{lll}0.68 & 0.11 \quad 0.05\end{array}$

0.31

0.0011

0.0001

44.1

64.1

manure

(NS)

547

548

549

550 
$552 \quad$ Figure 1

Figure 1

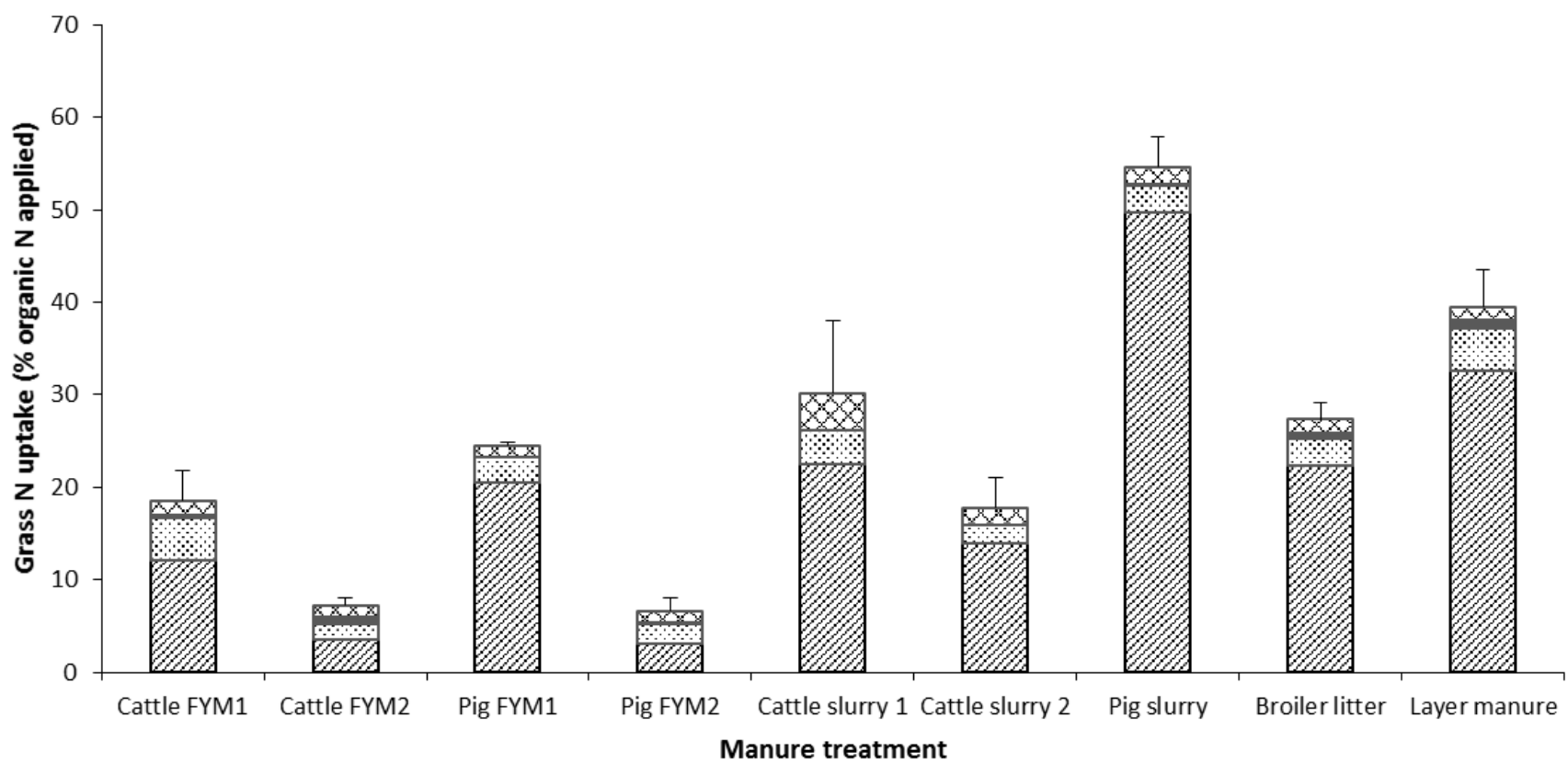

553 
Figure 2

556

557

Figure 2

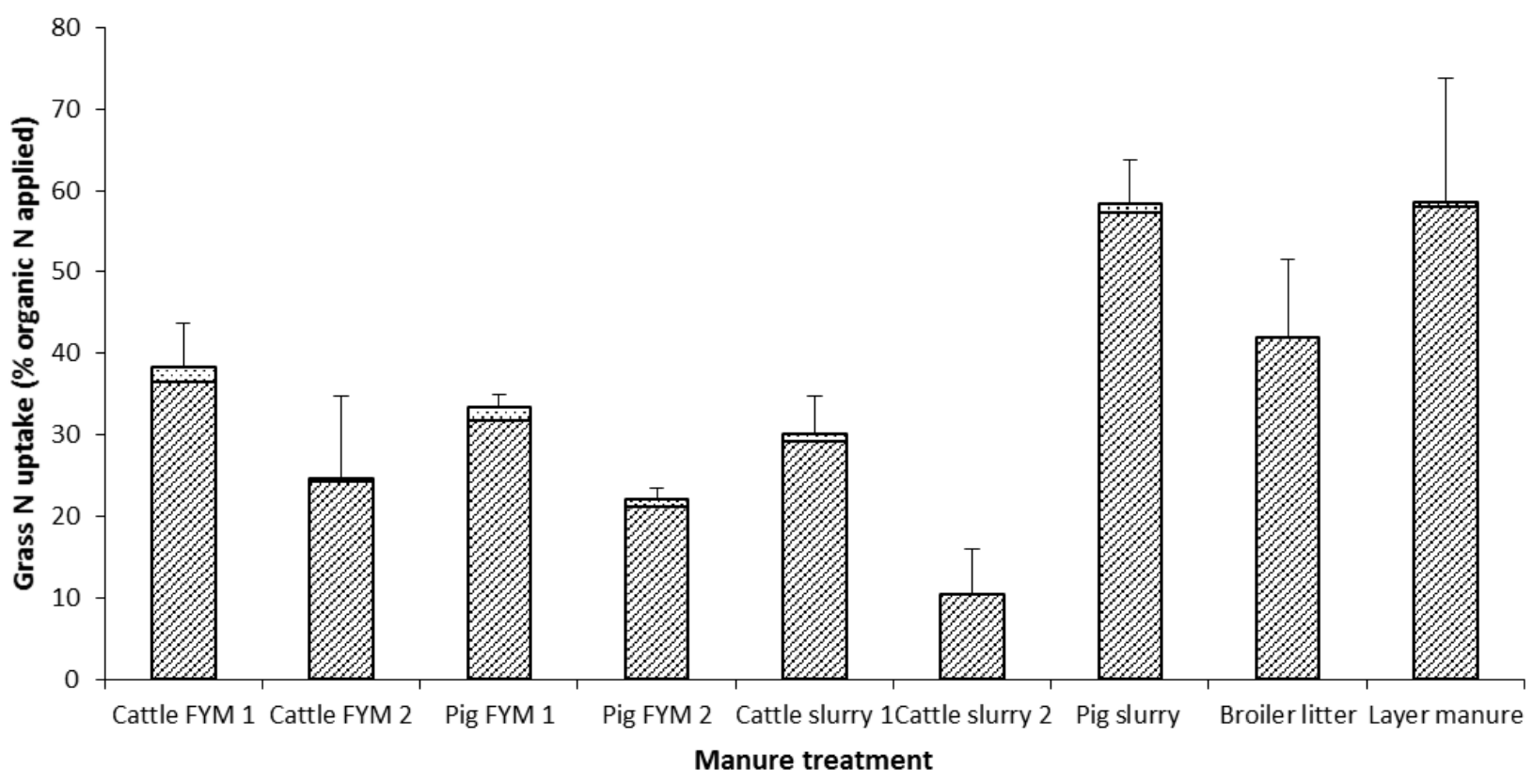

558

口 June 1996 - July 1997 Uuly - October1997

559

560 
Figure $3 \mathrm{a}$

Fig. 3a
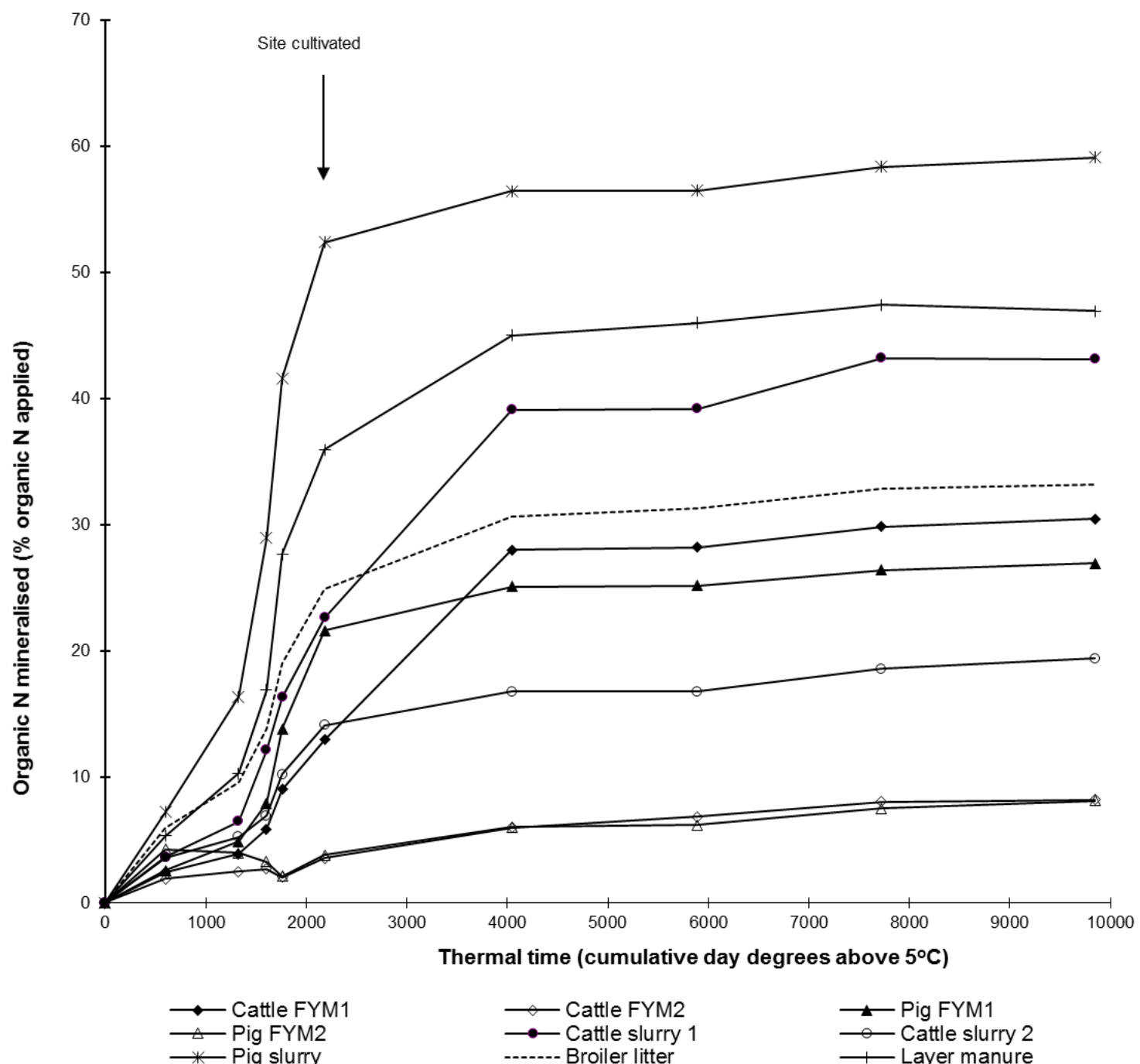

$\checkmark$ Cattle FYM2

$\longrightarrow$ - Cattle slurry

Broiler litter

— Pig FYM1

- Cattle slurry 2

- Layer manure

562 
Figure $3 b$

Fig. $3 b$.

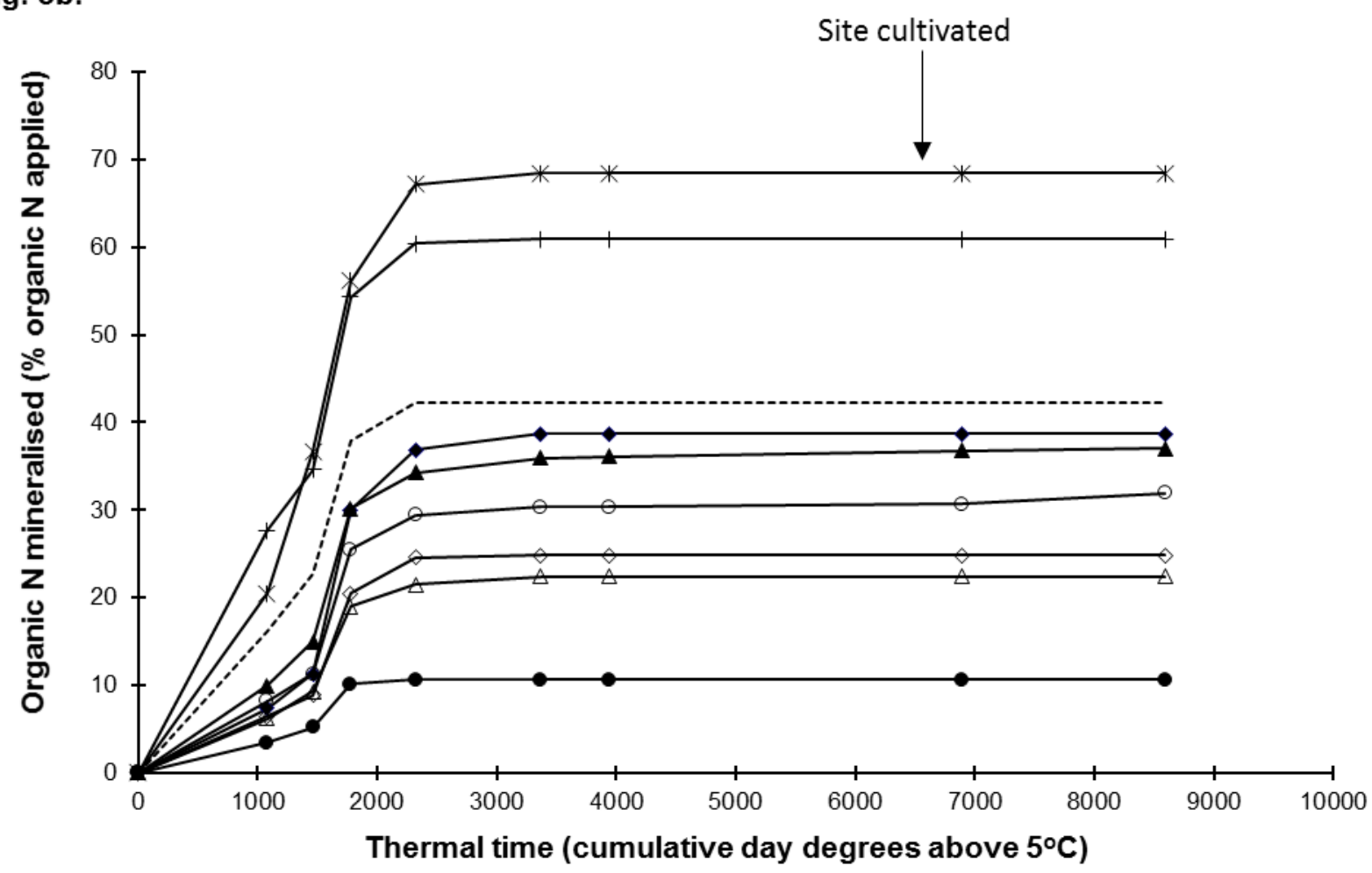

$\longrightarrow$ Pig FYM 1

$\_$Cattle slurry 1

$\longrightarrow$ L Layer manure 
Figure 4a.

Fig. $4 a$

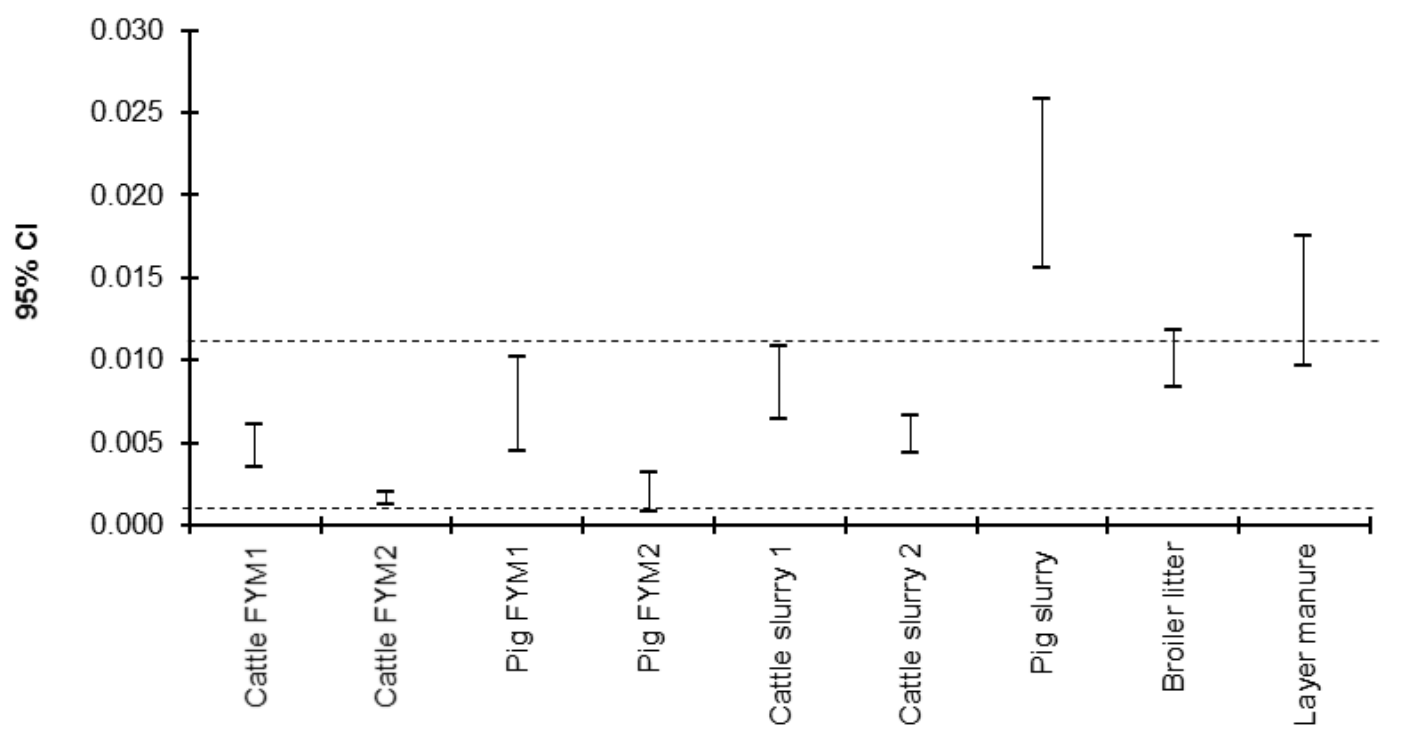

568 
569

Figure $4 b$.

570

571

Fig. 4b

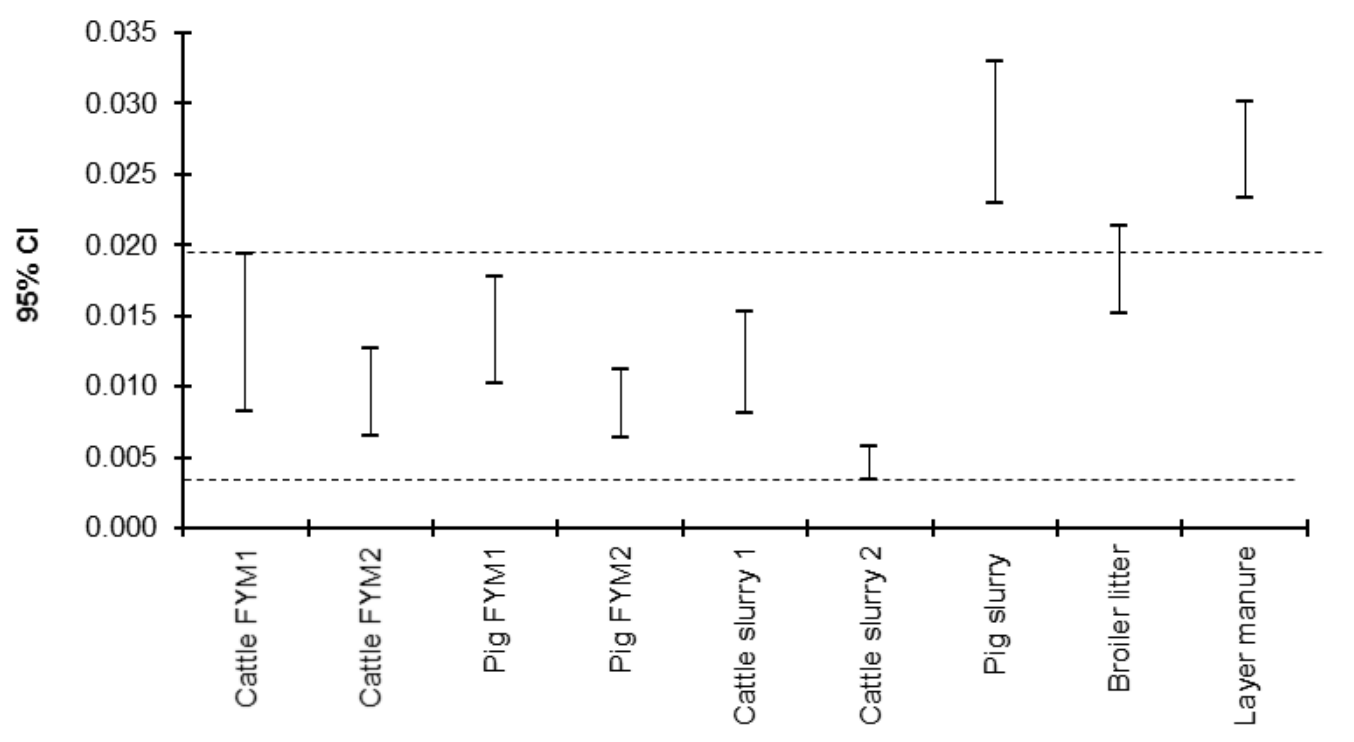

572 

Figure 5.

Fig. 5.

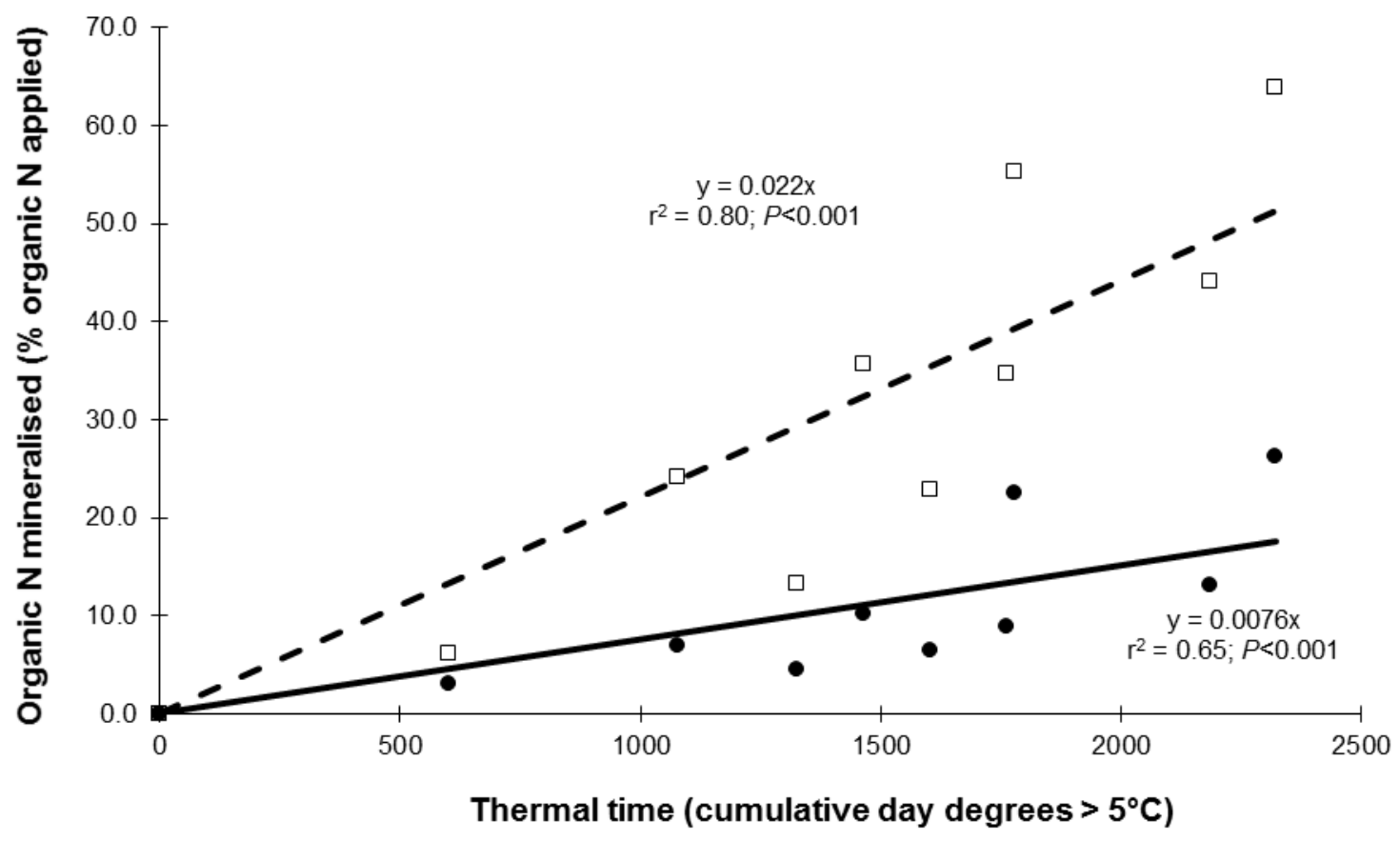

- Cattle FYM \& slurry \& Pig FYM $\square$ Pig slurry and layer manure 